\title{
Dental care for children with Congenital Zika Syndrome
}

\author{
Atendimento odontológico de crianças com Sindrome \\ Congênita do Vírus Zika
}

\author{
Rafaella Máximo Pereira de SIQUEIRA ${ }^{1}$ iD 0000-0002-1751-9074 \\ Aline Brito Alves da Silva MARINHO ${ }^{1}$ iD 0000-0002-7938-1058 \\ Maria Teresa Botti Rodrigues dos SANTOS² ID 0000-0002-1276-8012 \\ Glória Maria Pimenta CABRAL ${ }^{3}$ iD 0000-0003-0104-1448
}

\section{ABSTRACT}

There was a large increase in the number of newborns with microcephaly in Brazil between 2015 and 2017, mainly in the Northeast. This increase was associated with intrauterine Zika virus infection, which causes a congenital syndrome characterized by neurological, musculoskeletal, and sensory abnormalities. Despite the great worldwide repercussion, few studies about oral conditions in children with the syndrome have been published. This work aims to propose a guide for the dental care of these individuals on the basis of a literature review. Children with congenital Zika syndrome have a number of systemic comorbidities that affect their oral health and can compromise dental care. To date, no clinical protocol has been established for the dental care of children with congenital Zika syndrome. This is a pioneering study of great importance to orient dental professionals and promote the dental health of these children.

Indexing terms: Dentistry. Microcephaly. Zika virus.

\section{RESUMO}

Entre 2015 e 2017, houve um grande aumento no número de notificações de recém-nascidos com microcefalia no Brasil, principalmente na região Nordeste. Essa ocorrência foi associada ao vírus Zika, o qual foi responsável por uma síndrome caracterizada por problemas neurológicos, musculoesqueléticos, sensoriais, entre outros, denominada Síndrome Congênita do Vírus Zika. Apesar da grande repercussão mundial, poucos estudos acerca do comprometimento oral nessas crianças foram publicados. Dessa forma, este trabalho tem como objetivo propor a partir de uma revisão de literatura, um referencial de orientação para o atendimento odontológico destes indivíduos, a fim de embasar os profissionais dessa área. Observou-se que pessoas com Síndrome Congênita do Vírus Zika apresentam uma série de comorbidades sistêmicas que influenciam na sua condição oral e podem comprometer o atendimento odontológico, necessitando de cuidados especiais. Até então, nenhum protocolo clínico para o atendimento dessas crianças foi encontrado na literatura. Dessa forma esse estudo é pioneiro e de grande importância para direcionamento profissional e cuidado desses pacientes.

Termos de indexação: Odontologia. Microcefalia. Zika vírus.

1 Faculdade Centro Odontológico de Estudos e Pesquisas. Av. Esperança, 1194, Manaíra, João Pessoa - PB. Correspondência para / Correspondence to: RMP Siqueira. E-mail: <rafaellasiqueira@hotmail.com>.

2 Universidade Cruzeiro do Sul - Campus São Miguel, Faculdade de Odontologia. Jacuí, SP, Brasil.

${ }^{3}$ Instituto de Educação Superior da Paraíba, Faculdade de Odontologia. Cabedelo, PB, Brasil.

$\nabla \nabla \nabla v$

How to cite this article

Siqueira RMP, Marinho ABAS, Santos MTBR, Cabral GMP. Dental care for children with Congenital Zika Syndrome. RGO, Rev Gaúch Odontol. 2020;68:e20200014. http://dx.doi.org/10.1590/1981-863720200001420180012 


\section{INTRODUCTION}

Microcephaly is a condition in which the cephalic perimeter is smaller than the average for the age. It is classified as pathological when associated with neurological disorders [1]. Microcephaly is a clinical sign for impaired brain growth and may be due to various etiologies, such as genetic factors (autosomal dominant and recessive primary microcephaly, Down syndrome, Alagille syndrome, or Seckel syndrome, among others), maternal malnutrition, and maternal infection with toxoplasmosis, rubella, cytomegalovirus, or syphilis [2].

In the last four years, there was a large increase in the number of newborns with microcephaly in Brazil, mainly in the Northeast. This outbreak caught worldwide attention and was recognized as an emergency situation by international public health organizations. Several investigations were carried out to define its cause. It was promptly concluded that the Zika virus (ZIKV) was responsible not only for microcephaly but also for a series of neurological, musculoskeletal, and sensory abnormalities, characterized as a new syndrome, the congenital Zika syndrome (CZS) $[2,3]$.

\section{Systemic comorbidities of CZS}

Soon after the outbreak of microcephaly in northeast Brazil, it was observed that reduction in head circumference was only one of the signs of a complex syndrome, characterized mainly by neurological alterations. Imaging of the central nervous system using transfontanellar ultrasound, computed tomography, and magnetic resonance helped define CZS and differentiate it from other syndromes that include microcephaly and neurological anomalies [4].

Neuroimaging findings include cortical and subcortical calcifications, cortical malformations, simplified gyral pattern, abnormal neuronal migration, brainstem hypoplasia, cerebellar hypoplasia, decreased brain parenchymal volume, enlarged subarachnoid spaces, enlarged cisterna magna, large choroid plexus, hypoplasia or agenesis of the corpus callosum, and ventriculomegaly. Although microcephaly is the most striking feature of CZS, this condition is not always present. In some cases, children with CZS may develop hydrocephalus. The increase in cranial volume caused by this malformation may partially compensate for the reduction in cephalic perimeter resulting from microcephaly $[3,5,6]$.

Some infants exposed to ZIKV in utero were born with normal cephalic perimeter but developed postnatal microcephaly and/or hydrocephalus, showing that even children who are born without evident abnormalities should be monitored clinically [7].

Systemic comorbidities have been associated with neurological disorders and alterations in the affected regions. The following disorders have been reported by several authors: craniofacial disproportion; cerebral palsy; changes in muscle tone (hypertonia in most cases but also hypotonia); seizures (including cases of epileptic syndromes, such as Dandy-Walker malformation); hyperexcitability; irritability; respiratory disorders; sleep disorders; delayed development; speech and language disorders, such as dysphagia, laryngopharyngeal reflux, infantile speech, incoordination of sucking, swallowing, breathing, and chewing (caused by lesions to structures associated with the swallowing center, such as the brain stem); musculoskeletal disorders, such as arthrogryposis and clubfoot; cardiac alterations; genitourinary malformations; hearing abnormalities (arising from changes in otoacoustic emissions); and vision abnormalities (resulting from macular injury, chorioretinal atrophy, optic nerve abnormalities, and lesions in the thalamus, cerebellum, and corticalsubcortical region, structures responsible for analysis and interpretation of the information captured by the eyes) $[3,4,7,8]$.

The degree of impairment can vary greatly among individuals with CZS. However, some features such as delayed development, vision alterations, and speech and language disorders are present in most children, as reported by Siqueira et al. [5]. Visual impairment affects the learning process and the development of functional activities. Follow-up studies on the neuropsychomotor development of this population are fundamental for a greater understanding of the problem [8].

Diagnosis of ZIKV infection was a challenge, especially at the time of the outbreak, because of the simultaneous outbreaks of other arbovirus infections and difficulties in laboratory confirmation using tests available in public health services (serological testing and reverse transcription polymerase chain reaction, RT-PCR). Serological testing is limited by the possibility of cross-reaction with other viruses, and RT-PCR can detect ZIKV infection only 
during the acute viremia phase, which occurs up to 7 days after the onset of symptoms. Important advances are being made to detect ZIKV in saliva by reverse-transcription loop-mediated isothermal amplification (RT-LAMP). Saliva samples can be obtained non-invasively, increasing acceptance by patients, and ZIKV may remain for a longer period in saliva than in serum, although at lower concentrations [9].

An increasing number of children have been diagnosed with this syndrome in recent years; however, few studies are available in the literature regarding its implications on dental health.

\section{Dental characteristics of CZS}

Santana et al. [10] reported that children with microcephaly are more susceptible to oral abnormalities. According to Leite \& Varellis [11]. periodontal diseases, dental caries, malocclusion, micrognathia, delayed tooth eruption, dysphagia, bruxism, and dental traumas are present in children with this condition. Pereira et al. [12] reported that individuals with microcephaly often have hypotonia, microstomia, retrognathic mandible, abnormal palate formation, and wide space between teeth.

As occurs with systemic comorbidities, in which the prevalence of complications may vary among individuals, dental alterations may be present or not in patients with CZS. Delgado et al. [13] reported a case of an infant with microcephaly, followed-up from 3 to 20 months of age, who had no oral disorders. Cavalcanti [14], on the other hand, observed altered muscle tone in children with microcephaly attending a reference center for auditory, physical, intellectual, and visual rehabilitation in Campina Grande, Paraíba, and suggested that this complication might lead to dysphagia, delayed eruption of deciduous teeth, changes in the sequence of dental development, and enamel hypoplasia. Aguiar et al. [15] evaluated 74 children with microcephaly caused by or suspected to be caused by ZIKV infection in the same city and observed that in most children, the first deciduous teeth to erupt were mandibular central incisors at 12 months of age. In João Pessoa, Paraíba, 54 children with microcephaly potentially associated with CZS were evaluated and the following oral changes were observed: delayed eruption of deciduous teeth, changes in eruption sequence, peg-shaped teeth, fused teeth, enamel defects (opacity and hypoplasia), cleft lip and palate, bruxism, and related injuries (lip, tongue, and hand biting) [5]. In a study by Cavalcanti et al. [16], 79 children with CZS were followed-up for 24 months for signs and symptoms related to deciduous tooth eruption. The authors observed that all children had some form of dental manifestation, of which the most common were increased salivation, irritability, and gingival pruritus. Fonteles et al. [17] evaluated the lingual frenulum of 54 children with CZS in Pernambuco and observed that many children had a posteriorly positioned lingual frenulum and, in some cases, the frenulum was hidden behind a mucous curtain.

Although it is known that children with CZS require special care from all health professionals and that follow-up by dental surgeons is necessary from an early age, there is a lack of theoretical basis to orient their care. This study aims to propose a guide for the dental treatment of children with CZS on the basis of a literature review.

A search of the literature was carried out in the Cochrane, BVS Virtual Health Library, Pubmed, and Scielo databases using the keywords "microcephaly" and "dentistry." The inclusion criteria were articles published in Portuguese or English between 2000 and 2018 related to CZS. Of the 80 articles retrieved in the initial search, 18 were selected after reading the titles (phase 1) and, subsequently, 8 were excluded after reading the abstracts (phase 2). Thus, 10 articles were read in full (phase 3), of which one was excluded. In total, 9 papers were included in this study (Figure 1). On the basis of the information presented in the selected articles, we elaborated a guide to orient dental care professionals in the care of children with CZS. To date, no such guide has been published in the literature.

\section{DISCUSSION}

Because CZS is a recent condition, studies that analyze alterations in the maxillofacial complex are still incipient, and there are no guides for the clinical care of children with CZS in the literature. The dental surgeon, as part of a multidisciplinary and specialized team, should be prepared for the care, treatment, and follow-up of these individuals in public and private health systems $[12,14]$. Technical and scientific improvements in the treatment of the most frequent dental problems as well as proper 


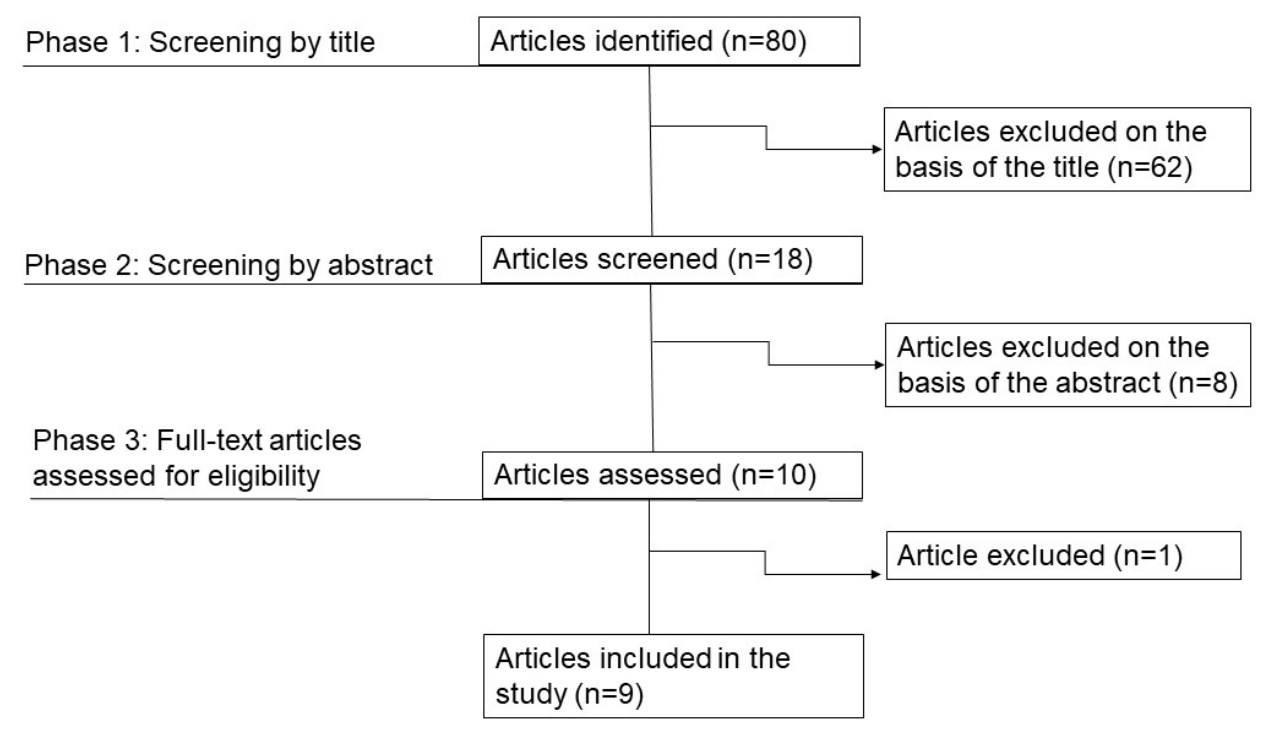

Figure 1. Flow diagram of the literature search.

conduct and use of techniques in each case are necessary to ensure high-quality care [11].

Children with neurological impairment usually do not respond to stimuli and commands, which makes it difficult to control dental biofilm and makes them dependent on assistance from family members or caregivers for personal and oral hygiene [15]. Individuals with microcephaly are considered at high risk for the development of diseases of the oral cavity and have a great need for preventative dental care. Participation of the family and/or caregiver is fundamental for treatment success and promotion of oral health [12].

Dental professionals must provide appropriate guidance to parents/caregivers during the first months of life of children with CZS regarding their oral hygiene and dietary habits, control of dental biofilm, and adequate use of fluoride. It is also necessary to establish a preventive program with regular appointments, thereby helping children and their families to achieve a better quality of life $[13,14]$.

Oral hygiene should be performed at least twice a day. This practice involves dental flossing (dental floss can be attached to a rod to facilitate the action) and tooth brushing. A toothbrush with a head size suitable to the child's oral cavity and with soft bristles should be used. Fluoride toothpaste (1000 ppm F) must be used after eruption of the first deciduous tooth. To avoid the development of dental fluorosis, the amount of toothpaste should be equivalent to the size of half a grain of rice for children up to 2 years of age, the size of a grain of rice for children between 2 and 4 years of age, and the size of a pea for children older than 4 years $[18,19]$.

Fluoride toothpaste is recommended despite the risk of developing fluorosis from ingestion because these children are at high risk for dental decay. Thus, additional care should be taken in controlling the amount of toothpaste used and removing toothpaste foam from inside the mouth, as children with CZS generally cannot spit $[18,19]$.

Dental disease prevention and treatment in people with disabilities is a challenge [13]. Individuals with CZS are prone to comorbidities associated with oral and dental problems and therefore require special attention. We emphasize that the first step towards an adequate treatment plan for CZS patients is a thorough anamnesis focused on collecting information about comorbidities. Detailed investigation allows for appropriate precautions to be taken.

A study conducted by Santos et al. [20] showed that children with cerebral palsy are more likely to have dental caries than children in the general population. The condition is also associated with higher plaque index, delayed eruption of permanent molars, and higher incidences of malocclusion, oral respiration, and bruxism [20]. In other words, children with cerebral palsy are a high-risk group for cavities and dental diseases. 
In the case of hypertonia, a common symptom in congenital or acquired neurological disorders, positioning patients in the dental chair may be particularly challenging. Involuntary movements make it difficult to open the patient's mouth and conduct clinical procedures and may necessitate use of mouth openers and tongue retractors [21].

Hypotonia of facial muscles is associated with lip incompetence, malocclusion, speech articulation disorders, and oral breathing. Respiratory disorders can also lead to oral breathing, as they may cause abnormal tongue posture, open bite, and Class II malocclusion. These associations are evidence of the intimate relationship between orofacial structures and stomatognathic system functions [22].

The risk of seizures during dental care should be considered in patients with epilepsy, especially those with uncontrolled epilepsy. Patients should be well rested, medicated, and assessed for convulsive seizure history at each consultation. Stimuli that could trigger epileptic discharges, such as a light source directed at the eye, should be completely avoided. Procedures should be brief to reduce stress and tiredness, which can also lead to seizures $[21,23]$. If a seizure occurs, dental procedures should be interrupted, the chair should be reclined to $180^{\circ}$ and lowered close to the floor, and the patient should be placed on her or his side with the head raised to prevent bronchoaspiration of secretions or dental materials. Patients may bite their tongue, cheeks, and lips during an epileptic event [23]. Pharmacological treatment, protective devices, or surgical treatment may be necessary to prevent seizure-related injuries [5].

Anticonvulsant medication and pediatric formulations often have low $\mathrm{pH}$, high viscosity, and high sugar content to mask their bitter taste, but this also makes them cariogenic $[14,15]$. Another factor to consider is that drugs prescribed for CZS may have adverse effects on the buccal cavity, including ulceration, xerostomia, stomatitis, glossitis, and gingival hyperplasia [23].

Children with global developmental delay may show delayed somatic growth, which in turn is associated with delayed tooth eruption, as reported by Aguiar et al. [5] and Siqueira et al. [15].

Dysphagia, defined as difficulty in swallowing and chewing, is common in conditions affecting the neurological or neuromuscular systems. It increases the risk of fluid and food aspiration and respiratory implications, such as pneumonia. Dysphagic patients are at increased risk for choking and suffocation during dental procedures, and care is required to avoid accidents. Important recommendations are use of a saliva ejector, low-speed drilling, and avoiding placing the patient with the head and trunk in horizontal position $[5,24]$.

Gastroesophageal reflux may be caused by neurogenic factors, is common in childhood, and can lead to dental erosion, which has a prevalence of $19 \%$ among children with neurological impairment. Other consequences of gastroesophageal reflux are a burning sensation in the mouth, sensitive tongue and teeth, heartburn, palatal erythema, loss of vertical dimension, and aesthetic problems [25].

Delayed tooth eruption associated with phonoaudiological immaturity can result in delayed introduction of solid foods and, as a consequence, nutritional problems [15]. Soft foods tend to adhere to dental surfaces, increasing the risk of caries.

As occurs in hypertonia, musculoskeletal disorders may prevent patients from remaining in the dental chair position. It is important to ensure that dental facilities be accessible to individuals with physical disabilities.

Individuals with congenital heart defects are at increased risk for bacterial endocarditis, mainly in the absence of medical treatment. Antibiotic prophylaxis is indicated before invasive procedures and should be defined in conjunction with a cardiologist prior to any dental treatment $[5,26]$.

Auditory and visual impairments interfere with communication, especially when both senses are affected. Because treatment success is closely related to the quality of communication between dentist and patient, it is highly advisable that hearing-impaired or visually impaired patients are accompanied by a family member or caregiver who can help the dentist establish a relationship with the patient [27]. The greater the extent of the patient's disability, the greater the dedication, patience, creativity, and communication capacity of the dental practitioner should be [21].

Slayton et al. [28] observed that enamel hypoplasia in deciduous teeth is common among children with cerebral palsy, intellectual deficiency, or hearing impairment, suggesting that systemic disorders interfere with neurological and dental development. Few studies have been conducted in Brazil on enamel development defects in the primary dentition. Enamel defects may result in aesthetic problems, dental sensitivity, and increased risk of caries [29], which implies the need for a strict followup with frequent visits for control of dental biofilm and 
fluoride application. We recommend weekly application of fluorinated varnish containing $5 \%$ of sodium fluoride for four consecutive weeks. Dentin caries and caries on cuspid teeth require early restoration. Glass ionomer cement is preferred over other cements because its adhesion and fluoride-releasing properties contribute to the remineralization of adjacent tissues [30].

Cleft lip and cleft palate can be present in individuals with CZS. These serious malformations require early surgical intervention to prevent systemic complications and severe functional and aesthetic sequelae [5].

Bruxism is very prevalent in the CZS population and is closely related to neurological disorders that trigger involuntary movements, biting, and grinding. Gastroesophageal reflux and oral breathing may also lead to this parafunction in children [31]. If treatment of bruxism is necessary in children with CZS, a multidisciplinary approach should be considered, including restorative procedures, occlusal splint therapy, pharmacologic therapy (benzodiazepines and muscle relaxants), psychological therapy, physiotherapy, acupuncture, orthodontic treatment, and application of botulinum toxin. Systemic etiological factors should be identified and treated [32].

Manufacturing an occlusal splint for a child with CZS is a difficult task involving a series of steps to shape the device and establish centric occlusion contacts. If the child's dental arches are not fully developed, the device is a problem in itself, posing a risk of aspiration and choking [31].
The safety of botulinum toxin treatment in children with systemic manifestations is not well established and should be considered with caution. According to Freitas et al. [32], this invasive approach can affect facial growth and tooth alignment.

Disease-related injuries are most frequently caused by bites during spasms or seizures and can include damage to the lips, tongue, jugal mucosa, and even hands. Pharmacological therapy, intraoral or extraoral devices, and, as a last resort, dental extraction may be used [33].

Currently, there are many resources available for the dental care of normal patients but few for that of patients with neurological complications, who also require access to high-quality dental treatments for a better quality of life. Efforts for the improvement of their dental health and care are pointless if not taken in conjunction by the different health professionals. Thus, the dental surgeon must pay attention not only to the development of dental health but also to the overall development of the individual, seeking effective information exchange with other health professionals and promoting thorough clinical care. In this manner, the dental professional can help serve the health needs of patients, restore their well-being, and enable their integration into their social environment [21].

Chart 1 shows recommendations for the dental care of patients with CZS elaborated on the basis of the available literature. Possible comorbidities and their risk factors are presented.

Chart 1. Recommendations for the dental treatment of children with congenital Zika syndrome.

\begin{tabular}{|c|c|}
\hline Challenge & Recommendations \\
\hline Anamnesis & Perform a thorough anamnesis to identify comorbidities. \\
\hline Invasive procedures & Cardiologic examination is needed before performing invasive procedures in patients with cardiac impairment. \\
\hline Instruction to caregivers & $\begin{array}{l}\text { Instruct caregivers on the importance of strict oral hygiene using fluorinated toothpaste (1000 ppm F) and the appropriate } \\
\text { amount of toothpaste to the age range. Remind caregivers of the importance of removing the foam after brushing. }\end{array}$ \\
\hline Enamel defects & $\begin{array}{l}\text { Perform frequent topical fluoride applications in case of enamel defects (weekly application of fluorinated varnish containing } \\
5 \% \text { sodium fluoride for four consecutive weeks). Cavitated hypoplastic lesions with dentin exposure or involving cuspid } \\
\text { teeth require early restoration using glass ionomer cement. }\end{array}$ \\
\hline Bruxism & $\begin{array}{l}\text { Treat the patient in conjunction with a neurologist to minimize the condition using muscle relaxants, muscle relaxation } \\
\text { exercises, and warm compresses on the masseter region. }\end{array}$ \\
\hline Self-injury & $\begin{array}{l}\text { Depending on the traumatized region, it is indicated to polish the incisal or occlusal surfaces of the teeth; use protective } \\
\text { devices, such as mouthguard and gloves; and contact a neurologist to prescribe medications for the control of spasms and } \\
\text { seizures. Dental extraction should be seen as a last resort and should only be performed if all other methods have failed. }\end{array}$ \\
\hline Malocclusion & $\begin{array}{l}\text { Periodic follow-up should focus on reducing malocclusion. Depending on the systemic comorbidities, indicate orthodontic } \\
\text { or orthopedic treatment. }\end{array}$ \\
\hline Comorbidities & Multidisciplinary treatment is recommended to improve muscle tone, swallowing, and breathing and treat comorbidities. \\
\hline
\end{tabular}




\section{CONCLUSION}

Individuals with CZS have a number of systemic comorbidities that affect their oral health and can compromise dental care. The dental characteristics of children with CZS include malocclusion and high-risk of developing dental caries.

Clinical protocols for the care of these children are not found in the literature. Specific information on the dental care of this patient group, which has been rapidly increasing in recent years, is of utmost importance for the establishment of multidisciplinary treatment plans, instruction of dental professionals, and development of health policies targeted at this population. Longitudinal studies are necessary for the follow-up of individuals with CZS throughout the stages of life.

\section{Collaborators}

All authors contributed substantially to the elaboration of this manuscript and assume full responsibility for its content.

\section{REFERENCES}

1. Araújo JSS, Regis CT, Gomes RG, Tavares TR, Santos CR, Assunção PM, et al. Microcephaly in northeast Brazil: a retrospective study on neonates born between 2012 and 2015. Bull World Health Organ. 2016 nov; 94(11):835-840. http://dx.doi.org/10.2471/BLT.16.170639

2. Brasil. Ministério da Saúde. Secretaria de Vigilância em Saúde/ Secretaria de Atenção à Saúde. Zika: abordagem clínica na atenção básica. Brasília: Ministério da Saúde; 2016 [citado 2018 Ago 18]. Disponível em: <http://production.latec.ufms. br>.

3. Brasil. Ministério da Saúde. Secretaria de Vigilância em Saúde/ Secretaria de Atenção à Saúde. Orientações integradas de vigilância e atenção à saúde no âmbito da Emergência de Saúde Pública de importância Nacional. Brasília: Ministério da Saúde; 2017 [citado 2018 Ago 18]. Disponível em: <bvsms. saude.gov.br>.

4. Eickmann SH, Carvalho MD, Ramos RC, Rocha MA, Linden V, Silva PF. Zika Virus Congenital Syndrome. Cad Saude Publica. 2016 jun;32(7):1-3. http://dx.doi.org/10.1590/0102$311 \times 00047716$

5. Siqueira RMP, Santos MTBR, Cabral GMP. Alterations in the Primary Teeth of Children with Microcephaly in Northeast Brazil: A Comparative Study. Int J Paediatr Dent. 2018;1-10. http://dx.doi.org/10.1111/ipd.12402

6. Peixoto Filho AAA, Freitas SB, Ciosaki MM, Oliveira LNE, Santos Júnior OT. Computed Tomography and Magnetic Ressonace Imaging Finding in Infants with Microcephaly Potentially
Related to Congenital Zika Virus Infection. Radiol Bras. 2018;: 1-4. http://dx.doi.org/10.1590/0100-3984.2016.0135

7. Feitosa IML, Schuler-Faccini L, Sanseverino MTV. Aspectos importantes da Síndrome da Zika Congênita para o pediatra e o neonatologista. Bol Cient Pediatr. 2016;5(3):75-80.

8. Botelho ACG, Neri LV, Silva MQF, Lima TT, Santos KG, Cunha RMA, et al. Presumed congenital infection by Zika vírus: findings on psychomotor development - a case report. Rev Bras Saude Matern Infant 2016;16(supl 1):s45-s50. http:// dx.doi.org/10.1590/1806-9304201600s100004

9. Sabalza M, Yasmin R, Barber CA, Castro T, Malamud D, Kim $B J$, et al. Detection of Zika Virus using reverse-transcription lamp coupled with reverse dot blot analysis in saliva. Plos One. 2018 fev;13 (2). http://dx.doi.org/10.1371/journal. pone.0192398

10. Santana JF, Santos GA, França LC, Ramos LVS, Lima LFA, Maia CS. The influence of oral health microcephaly. IJVD. 2018;1(5). http://dx.doi.org/10.28933/ijvd-2018-05-1805

11. Leite CN; Varellis MLZ. Microcefalia e a Odontologia brasileira. J Health NPEPS. 2016;1 (2):297-304.

12. Pereira SMS, Borba ASM, Rosa JFL, Carvalho CN, Maia Filho EM, Ferreira MC, et al. Zika vírus e o futuro da Odontologia no atendimento a pacientes com microcefalia. Rev Investig Biomed. 2017;9:58-66. http://dx.doi.org/10.24863/rib.v9i1. 89

13. Delgado GKG, Cavalcanti MEA, Mendes PA. Abordagem Odontológica em um bebê portador de microcefalia: relato de caso. RvACBO. 2017;26 (2): 92-98. ISSN 2316-7262.

14. Cavalcanti AL. Chalenges of Dental Care for Children with Microcephaly Carrying Zika Congenital Syndrome. Contemp Clin Dent. 2017;8(3):345-346. http://dx.doi.org/10. 4103/0976-237X.214553

15. Aguiar YPC, Alencar CRB, Cavalcanti SALB, Cavalcanti AFC, Melo ASO, Cavalcanti AL. Chronology of the first deciduous tooth eruption in brazilian children with microcephaly associated with zika virus: a longitudinal study. Pesq Bras Odontopeditr Clin Integr. 2018;18 (1):3982. http://dx.doi. org/10.4034/PBOCI.2018.181.16

16. Cavalcanti AFC, Aguiar YPC, Melo ASO, Leal JIBF, Cavalcanti $A L$, Cavalcanti SDLB. Teething symptoms in children with congenital Zika Syndrome: a 2-year follow-up. Int J Paediatr Dent. 2018;29(141):74-78. http://dx.doi.org/10.1111/ipd.12 431

17. Fonteles CSR, Ribeiro EM, Santos MAS, Leite RFP, Assunção GS, Monteiro AJ. Lingual Frenulum Phenotypes in Brazilian Infants With Congenital Zika Syndrome. Cleft Palate Craniofac J. 2018;55(10):1391-1398. http://dx.doi.org/10.1 177/1055665618766999

18. Abanto J, Celiberti P, Braga MM, Vidigal EA, Cordeschi T, Haddad $A E$, et al. Effectiveness of a preventive program based on caries risk assessment and recall intervals on the incidence and regression of initial caries lesions in children. Int J Paediatr Dent. 2015; 25:291-299. http://dx.doi.org/10.1111/ipd. 12144

19. Wright JT, Hanson N, Ristic H, Whall CW, Estrich CG, Zentz RR. Fluoride toothpaste efficacy and safety in children younger than 6 years: a systematic review. J Am Dent Assoc. 2014;145(2):182-189. http://dx.doi.org/10.14219/jada.2013.37 
20. Santos MTBR, Masiero D, Novo NF, Simionato MR. Oral Conditions in Children with Cerebral Palsy. J Dent Child. 2003;70(1):40-46

21. Peres ACD, Asano C, Carvalhaes CLL, Cesar MF. Alterações clínicas dos pacientes com lesão encefálica adquirida que interferem no tratamento odontológico. Acta Fisiatr. 2011;18(3):119-123.

22. Berwig LC, Silva AMT, Busanello AR, Almeida FL, Bolzan GP, Hennig TR, et al. Alterations in breathing mode, occlusion and speech in school - age children: occurrences and relationships. Rev CEFAC. 2010;12(5):795-802. http://dx.doi. org/10.1590/S1516-18462010005000094

23. Barbério GS, Santos PSS, Machado MAAM. Epilepsia: condutas na prática odontológica. Rev Odontol Univ Cid São Paulo. 2013;25(2):141-146.

24. Klafke JFP, Paes MEM, Cover C, Brito LV, Santos IA, Ribeiro NCDO, et al. Fisiologia da mastigação e deglutição. Ação Odonto. 2017;(2).

25. Rocha CT, Turssi CP, Castanheira SB, Corona SAM. Erosão dental na infância e sua associação com o refluxo gástrico. Pesq Bras Odontopediatr Clin Integr. 2011;11(2):305-310. http://dx.doi.org/10.4034/PBOCl.2011.112.24

26. Pamplona MC, Soriano YJ, Pérez MGS. Dental considerations in patients with heart disease. J Clin Exp Dent. 2011;3(2):97-105. http://dx.doi.org/10.4317/jced.3.e97

27. Haddad AS (Org.). Odontologia para pacientes com necessidades especiais. São Paulo: Santos; 2007.
28. Slayton RL, Warren JJ, Kanellis MJ, Levy SM, Islam M. Prevalence of enamel hypoplasia and isolated opacities in the primary dentition. Pediatr Dent. 2001;23:32-36.

29. Lunardelli SE; Peres MA. Prevalence and distribuition of developmental enamel defects in the primary dentition of pre-school children. Braz Oral Res. 2005;19(2):144-149. http://dx.doi.org/10.1590/S1806-83242005000200013

30. Fragelli CMB, Souza JF, Jeremias F, Cordeiro RCL, SantosPinto $\mathrm{C}$. Molar incisor hypomineralization $(\mathrm{MIH})$ : conservative treatment management to restore affected teeth. Braz Oral Res. 2015;29(1):1-7. http://dx.doi.org/10.1590/1807-3107 BOR-2015.vol29.0076

31. Souza VAF, Abreu MHNG, Resende VLS; Castilho LS. Factors associated with bruxism in children with developmental disabilities. Braz Oral Res. 2015;19(1):1-5. http://dx.doi.org/10. 1590/1807-3107BOR-2015.vol29.0009

32. Freitas AR, Dias MM, Falcão Filho HBL, Vasconcellos AA. Sleep bruxism in children prevalence and multidisciplinary therapy. Oral Health Dent Manag. 2014;13(4):897-901.

33. Limeres J, Feijoo JF, Baluja F, Seoane JM, Diniz M, Diz P. Oral Self-Injury: na update. Dental Traumat. 2013;29(1):8-14. http://dx.doi.org/10.1111/j.1600-9657.2012.01121.x

Received on: 30/10/2018 Final version resubmitted on: 24/1/2019 Approved on: 8/3/2019 